This is a self-archived version of an original article. This version may differ from the original in pagination and typographic details.

Author(s): McEvoy, Eileen; Heikinaro-Johansson, Pilvikki; MacPhail, Ann

Title: An exploration of the influence of professional relationships on the career pathways of physical education teacher educators

Year: 2019

Version: Accepted version (Final draft)

Copyright: @ 2019 SAGE Publications

Rights: In Copyright

Rights url: http://rightsstatements.org/page/InC/1.0/?language=en

Please cite the original version:

McEvoy, E., Heikinaro-Johansson, P., \& MacPhail, A. (2019). An exploration of the influence of professional relationships on the career pathways of physical education teacher educators.

European Physical Education Review, 25(4), 913-928.

https://doi.org/10.1177/1356336×18785106 


\title{
An Exploration of the Influence of Professional Relationships on the Career Pathways of Teacher Educators
}

\section{Eileen McEvoy, Pilvikki Heikinaro-Johansson \& Ann MacPhail}

European Physical Education Review

Published online July 2018

Final accepted version

\begin{abstract}
This paper focuses on the professional journeys of 14 mid- and late-career teacher educators in seven countries within the subject area of physical education. Data was gathered through two rounds of semi-structured interviews and revealed a strong emphasis on the professional relationships impacting upon participants' entry to and development within the profession. Career interest development, career choice and career performance were all affected by the people with whom participants formed relationships throughout their careers. The findings are discussed with reference to the role of teacher educators in selecting, encouraging and supporting their teacher education colleagues.
\end{abstract}

Keywords: teacher educator, physical education, career, relationship, mentor

\section{Introduction}

Research examining those who teach teachers has been forthcoming with increasing frequency over the past 15 years. Broad themes receiving attention have included the professional identities of teacher educators (Erickson et al., 2011; Hökkä et al., 2016; Izadinia, 2014; Tryggvason, 2012), their professional development (Ben-Peretz et al., 2010; MacPhail, 2017; Swennan and Bates, 2010; Van der Klink et al., 2017), and their practice (Bronkhorst et al., 2011; Gelfuso, 2017; Vanassche and Kelchtermans, 2014). There has also been a significant presence of teacher educators willing to share their own professional stories, practices and insights with a view to informing teacher education practice and pedagogy, as reflected in a number of recent edited books (Loughran and Hamilton, 2016; Swennen and Van der Klink, 2009; Williams and Hayler, 2015).

Regarding the professional journeys of teacher educators, much empirical research to date has focused on the initial socialisation and early-career experiences of this population, with particular reference to transitions from the role of school teacher to work in higher education (e.g. Harrison and McKeon, 2008; Russell and Loughran, 2010). Studies looking at the midand late-career stages of teacher educators have also emerged, although with less frequency (Griffiths et al., 2014; Kosnik et al., 2013; Montenegro Maggio, 2016). Griffiths and 
colleagues explored the career experiences and landmarks of 12 mid-career teacher educators in England. These authors found that as the teacher educators progressed through their careers their sense of professional identity increased as they were given professional acknowledgements and key management and research responsibilities. In their study, relationships with others were foregrounded as being a particularly important contextual factor influencing the professional journeys of participants. In her study of Chilean teacher educators, Montenegro Maggio (2016) stresses the social and cultural situatedness of career pathways of teacher educators. The work of Kosnik et al. (2013) focused on literacy teacher educators in four countries, exploring their knowledge, identities and career turning points. Their participants pointed to influential experiences, relational interactions and practices which shaped their professional identities and approach to their role. Most reported their careers had followed a serendipitous career path with few having planned to end up in academia.

It has been suggested that studying groups of academics within their professional fields can provide useful insights into the professional lives of contemporary academics (Boyd and Smith, 2016). Kosnik and colleagues have called for more discipline-focused research focused on the lives and work of mid- and late-career teacher educators, in line with the work they have completed with literacy teacher educators (Kosnik et al., 2015). The importance of uncovering the professional journeys and career decisions of mid- and late-career teacher educators lies in the explanatory value such research might hold for better understanding why it is these people, and not others, who are educating our future teachers, informing practice through research and shaping teaching and learning practice in the discipline of education. Over 25 years ago, Lawson called for more empirical research into those who teach teachers within the subject area of physical education. He argued for more research into their motivations, work contexts, professional communities, socialisation and career pathways. He also highlighted the importance of exploring the distribution of formal power and informal influence within disciplinary communities that determines 'who gets what, when, how much and why' (Lawson, 1991: 233).

A recent scoping review of literature investigated the literature on physical education teacher educators during the years since Lawson's seminal paper (McEvoy et al., 2015). The findings of this review indicate that, echoing the extant literature, little research has investigated the careers pathways of physical education teacher educators beyond the initial career stages. A recent special issue uncovered the joys, challenges and questions of 30 early career academics in the field of sport pedagogy across nine countries as they navigate neoliberal academic life (Enright et al., 2017). The study was innovative, seeing a group of professors openly provide advice in response to composite narratives reflecting the lived experienced of a group of early career academics. Richards and colleagues also recently focused on early career academics in physical education, investigating the doctoral student socialisation experiences of 32 physical education doctoral students in the US (Richards et al., 2017). Their findings, in keeping with those of an earlier study by Lee and Curtner-Smith (2011), demonstrated the importance of both supportive and challenging relationships to the development and early professional experiences of doctoral students. Self-studies and teacher educators' individual accounts of their own professional journeys have also contributed 
somewhat to our understanding of the careers and professional experiences of teacher educators in the field (e.g., Casey and Fletcher, 2012; Fletcher and Casey, 2014; Kirk, 2014; Kovar, 2004; MacPhail, 2011; Tannehill, 2005). However, the only identified paper involving an in-depth exploration of the careers of a group of later-career physical education teacher educators is that of Dodds (2005), which looked at the biographies, careers and socialisation of 54 female physical education teacher educators in the US, with a specific focus on participants' experiences of being mentored during their careers. Mentors were found to provide support, challenge, exposure to opportunities, and modelling of professional conduct during the participating teacher educators' careers.

Responding to this identified gap in the literature, the research presented in this paper explores the professional journeys of 14 mid- and late-career teacher educators in seven countries within the subject area of physical education. In particular, the research focuses on the professional relationships formed throughout participants' careers and how these relationships influenced their career pathways.

\section{Theory framing the study}

To assist in the elucidation of data related to the professional journeys of participants, we refer to Lent et al.'s (1994; 2000; 2002) Social Cognitive Career Theory (SCCT), which was useful in stretching our thinking regarding this topic. This theory is rooted in social cognitive theory (Bandura, 1986) and emphasizes cognitive-person variables that enable people to influence their own career development, as well as contextual variables that enhance or constrain personal agency.

There are three interlocking models within SCCT: career interest, career choice and career performance. All highlight the mediating effect of self-efficacy beliefs, outcome expectations and goal representations on career development. The interest model in SCCT specifies that individuals are likely to develop interest in activities in which they feel efficacious and from which they anticipate that there would be positive outcomes. The choice model views the development of career goals and choices as functions of the interaction between self-efficacy, outcome expectations and interest over time. Career choice is seen as a dynamic process in which the person and his/her environment mutually influence each other. An 'ability' factor, framed by one's achievement, aptitude, and past performance, is highlighted in the performance model. Ability serves as feedback from reality to inform one's self-efficacy and outcome expectation, which in turn influences performance goals and levels.

Although SCCT can be viewed as somewhat linear (with the interest model applying to a person prior to beginning a career, the choice model applying to the choice of career and the performance model affecting the in-career years), Lent et al. (1994) do indicate that the models can repeat throughout a person's lifespan. Our data led us to view the theory as representing a spiral, the different stages of which feed forward to further iterations of the interest, choice and performance models. This is particularly useful when thinking of teacher educators. Each of our participants had initially developed an interest in becoming teachers of physical education in school. However, after they experienced the first cycle of developing interest, making the choice to enrol in an undergraduate degree in physical education and reflecting on their performance (either as a student in higher education or, in some cases, as 
teachers in school), they then developed subsequent interest in becoming teacher educators/academics and made subsequent career choices which resulted in new performances to be reflected upon.

As the findings will illustrate, these cycles of interest development, career choice and performance were strongly affected by the people with whom participants formed relationships throughout their careers. As the most salient theme in the data, it is these relationships that will be the focus of the findings and discussion.

\section{Methodological approach}

This study was positioned within the social-constructivist paradigm, following a qualitative research design. Participants were purposively selected and invited to take part in two rounds of in-depth semi-structured interviews with the intention of recording and examining their voiced experiences and the meanings they attached to such experiences.

\section{Participants}

The selection of participants was influenced by a desire to include those in senior teacher education roles in order to investigate their professional journeys and experiences over time. There was also a wish to ensure a geographical spread of participants to allow for a cross section of experiences from different contexts. With these priorities in mind, participant selection entailed a combination of convenience and purposive sampling (Patton, 2002; Teddlie and $\mathrm{Yu}, 2007)$.

Participants were selected from among the 53 attendees at an international research seminar which focused on teacher education within physical education. The selection was made according to three criteria: (1) contributing to the education of secondary physical education teachers, (2) holding a senior position in a given faculty (at least senior lecturer/associate professor or equivalent), and (3) having at least 10 years of professional experience in the field of physical education with at least five of those years being as a physical education teacher educator in higher education. To ensure a geographical spread among participants, it was decided not to have more than four participants from any one country. Because eight participants from one country met the selection criteria, four of these were selected for participation based on obtaining a range and depth of professional experience to inform the research. Of the 15 teacher educators who met the selection criteria and who were invited to participate, all but one agreed.

Among the 14 teacher educators who participated in the research, there were seven women and seven men. At the beginning of the data collection period, six held the job title of senior lecturer, one was an assistant professor and seven were professors. It is acknowledged that these titles encompass different responsibilities in different contexts but the data demonstrated that all participants had a wealth of relevant experience through which to inform the research. At the beginning of the data collection period, the average number of years of experience as teacher educators among participants was 20, ranging from 6 to 38 years. All participants were based in universities, all but two held doctoral degrees, and the research/teaching/administration balance to which participants were expected to adhere varied according to their rank and institutional context. Participants were based in seven countries: Belgium, Finland, Germany, Ireland, New Zealand, Switzerland and the USA. It is 
important to note here that although this study is international in the sense that its participants are based in various countries, it is not a comparative study and the participants do not claim to represent the totality of views from their respective countries. Rather, they provide individual perspectives from a variety of contexts.

\section{Data collection}

In-depth semi-structured interviewing was the preferred data collection method for this study. Two rounds of individual in-depth semi-structured interviews were conducted. Two participants chose to conduct one of their interviews in person and respond to the questions for the other interview in writing. Of the 26 interviews conducted orally, nine were conducted in person at a location convenient to the participant (in an office or a quiet location at a conference). The other 17 interviews took place via Skype. The interviews lasted an average of 85 minutes. The average duration in the initial round of interviews was 68 minutes; the average in the follow-up interviews was 101 minutes. To increase the trustworthiness of the resulting data, each participant received a copy of his/her transcripts and was encouraged to clarify or comment on any aspects of the data after each interview.

The initial interviews, which took place in spring 2014, focussed on gaining a general overview of the participants' professional pathways and their experiences of working in the field. Their views on their subject area (physical education) were also explored during this initial interview. Questions in the initial interviews included: 'Please briefly describe your background i.e. how you came to be in your current position?' How would you describe your current position?' and 'What is it like to be a physical education teacher educator?'

Following preliminary analysis of the initial interviews and a reflection on findings from a concurrent review of literature (McEvoy et al., 2015), the choice was made to focus the follow-up interviews, which took place in autumn 2015, on an in-depth exploration of the professional journeys of participants (their entry to the profession, landmarks and turning points in their careers, supports and barriers to career development). Questions in the followup interview included: 'Looking back over your career, do you see particular moments/events/decisions/people as representing significant landmarks/turning points that shaped your professional journey or your development as a physical education teacher educator?' 'What would you say were the high points and low points in your career?' 'What factors affected your career decisions?'

Following the initial interview, each participant was also asked to provide a copy of his/her curriculum vitae. This artefact was useful both in confirming general details provided in the initial interview and as a prompt in examining career decisions and turning points in more depth in the follow-up interview.

\section{Data analysis}

There is a degree of subjectivity to be acknowledged at this point regarding the data collection and analysis conducted in this study so that the reader may make an informed judgement regarding the findings presented. The participants spoke in detail about their lived experiences as they recalled them. The recalling and telling of these lived experiences were, however, necessarily filtered through memory, the social construction of experiences by participants over time, and the social construction of experiences within the interview 
context. Following from this, participants' accounts were then analysed and interpreted by the first author, adding another layer of subjectivity. The second and third author acted as critical friends, encouraging reflexivity and challenging assumptions. We acknowledge that the social reality of another cannot be objectively accessed and known (Smith and McGannon, 2017). The intention, rather, is to present the themes identified in the process of data analysis, while acknowledging that other themes and interpretations also exist.

A descriptive approach was taken to the analysis of data (Silverman, 2013). The overall data corpus for this research consisted of transcriptions of 36 hours and 51 minutes of audio recordings as well as the two interview responses submitted in written form. In all, this represented 745 pages of data (299,533 words). While not wishing to quantify the qualitative, we provide these figures to give a sense of the scope of the data corpus. In addition to this data corpus, field notes taken by the first author before, during and after each interview, in addition to participants' curricula vitae, were referred to throughout the analysis process.

The first phase of analysis involved listening to the interviews a number of times to become familiar with the experiences and narratives shared by participants in a holistic manner before breaking the data up for further analysis. As part of this process of familiarisation with the data, a brief one/two-page summary of the full narrative shared by each participant was also created to serve as an aid in retaining the whole picture of each participant as the data analysis continued.

The second phase of analysis involved exporting the full data corpus to Excel where it was divided into meaning units. Meaning units are defined by Elliot and Timulak (2005: 153) as 'parts of the data that even if standing out of the context, would communicate sufficient information to provide a piece of meaning to the reader'. These meaning units were created by reading carefully through the data and as each new thought/piece of narrative was shared, a new unit was begun. In all, the data was divided into 2012 meaning units. The units were kept relatively large (approximately 150 words on average) so that the data did not become too fragmented and the clarity of the contextual meaning was retained. Each meaning unit was numbered chronologically so it could be located again within the context of the original interview at all stages of analysis. As each meaning unit was created, it was assigned to the 'domain' to which it pertained (Elliot and Timulak, 2005: 154). The domains created for our data corpus were 'professional journeys', 'professional views', 'professional contexts', 'roles/responsibilities/experiences' and 'research'. As the meaning units were large, they were often categorised within more than one domain, creating considerable overlap between domains.

The next phase of analysis involved categorising the meaning units within each domain. Within the professional journeys domain, for example, categories included those such as 'entry to teacher education', 'identity', 'support', 'influence', 'turning point' and 'decision'. Within each category, units were further coded through a constant comparison of meaning units until all the data were sorted (Rubin and Rubin, 1995). Within the 'entry to teacher education' category, for example, codes included 'being let in', 'prior relationships', 'chance', and 'showing promise'. 
The final phase involved looking across categories to identify themes which were common and provided insight into the professional journeys of participants. By far the most salient theme, and thus the focus of this paper, was the significant influence of professional relationships on the professional journeys of participants. Pseudonyms are used in the presentation of findings.

\section{Findings and discussion}

This section begins with an overview of the initial career aspirations of participants before going on to discuss the influence of professional relationships on: (i) the participants' entry to the teacher education profession, (ii) their key career landmarks, and (iii) their professional learning as teacher educators.

All participants shared a passion for their subject area and had begun their careers intending to teach physical education in school. The participants' backgrounds and socialisation saw them develop interest in the subject area through factors such as parental influence, influence of exemplary teachers, positive experiences of sport/physical activity, an affinity for education, a wish to improve education and a belief in the positive outcomes that could be achieved for young people through physical education. Their choice to enrol in undergraduate programmes in the subject area was influenced by both their sense that it was something in which they could succeed (self-efficacy) and that it would result in what they considered to be positive outcomes (e.g. job security, job satisfaction, etc.).

It is notable that none of the participants began with aspirations towards the positions in which they eventually found themselves. As Elina, from Finland, shared: 'I never thought I would stay here. In my mind, I was going to be a PE teacher in school. That was kind of my goal. But just the circumstances drew me here'. Similarly, Ian, from the USA, explained: 'I mean, I did not put down a 5-, or a 10-, or a 15-, or a 20-year plan and say this is what I wanna do or I want to become the leading scholar ... that was never my intention'. Andreas, from Germany, felt that: 'this is one thing that you cannot plan. You're just studying at one university and ... I think you're choosing the university because you want to become a teacher, a PE teacher. And it was, well, sort of an accident'. Jane, from New Zealand, explained that: 'if someone had said to me even 15 years ago that I would have [reached the position I have now] I would never have dreamed that I could do that'. This finding echoes the broader literature, in which teacher educators are often found to happen upon their careers in a somewhat unplanned, 'accidental' manner (Kosnik et al. 2013; Mayer et al. 2011).

Bloch (2012) describes the academic career path as similar to a funnel. At the top there are many $\mathrm{PhD}$ students entering but the funnel narrows quickly and only a few make it through the other side to a career in academia. It is worth interrogating further, therefore, what goes on inside this funnel and what determines who makes it through to the other side.

\section{Entry to the profession}

Morberg and Eisenschmidt (2009) remind us that there are commonly two routes to teacher education, one where a person remains in higher education, gains a $\mathrm{PhD}$, and begins to teach as part of their academic role, and another where a person teaches in a school setting for considerable time before returning to higher education and taking up an academic role. While 
six participants in the current study spent several years teaching physical education in schools before entering teacher education, the others found themselves taking a relatively direct route from their undergraduate physical education degrees to researcher and teacher education positions within universities. For most, their transition into the teacher education profession was eased by pre-existing relationships with staff in higher education. Of the six who were teachers of physical education for considerable lengths of time before entering teacher education, all had some prior relationship with those with whom they first worked in teacher education. In many cases, they had built some experience supervising teachers in schools or working on professional development or research with members of faculty:

There'd been a whole lot of new developments of senior school qualifications in physical education at that time and I was part of that development, I was leading it, or participating in it on behalf of our school, so I was working with those people who were also, who were leading it, essentially ... and so I guess when this job came up I guess that [gave me the feeling] that possibly [I] could do it, "cause [I] knew some of the people. (Jane, New Zealand)

I kind of became related with the university, they would send me practicum students, field experience students ... And it started me thinking and, you know, I kind of started seeking out opportunities at the university, became affiliated with [name of professor], and it kind of paved the way for me, you know, to move up. (Josh, USA)

I was a student who was in the faculty board and [later] I was head of academic affairs ... I was working with the professor of health sciences ... [that made me think that] it's okay that I am coming [to join the faculty from teaching]. (Hanna, Finland)

For those who remained in higher education without spending more than a year or two teaching in schools, many had also built relationships with influential faculty early on. Lars and Max, for example, developed professional relationships with professors while undergraduates:

After first year [as an undergraduate], [the professor] invited me to become a student assistant. For me, it was the beginning of a very long story. Because it was the first step in the university staff. It was an invitation to become a member of the group teaching students and it gave me the motivation or the feeling that I was interested in teaching physical education students. (Lars, Belgium)

[As an undergraduate student] I was successful, the lecturers and so on saw that I was very much in this field and was motivated to do that and so they gave me special tasks and this made me happy and proud. (Max, Switzerland)

Similarly, Mikko described the feeling of being 'let in' by a professor:

I knew that this [professor], his position, that it was going to open in some years. But still I knew that with only a master's degree it wouldn't be enough to get the position. And when [the professor], he told me that there is an open position I was thinking 
that, okay, this is a green light for my further studies to get the eligibility to apply for this position. So, that was the starting point. I was thinking that, okay, now they are letting me in. (Mikko, Finland)

This sense of being 'let in' to the profession was central to the early teacher education experiences of many participants. Most had formed relationships with existing faculty who were, in essence, 'gatekeepers' for the profession. This is not to suggest for a moment that participants did not enter the profession on merit. Rather, the data demonstrated that in many cases existing faculty identified some promise in the participants when they encountered them and endeavoured to nurture this promise and encourage their continuation towards positions within higher education.

Considering these findings from the perspective of SCCT, there are several interlocking factors at work here. We see in the data the sense of having been selected giving the participants 'motivation', making them 'happy and proud', that it was 'okay' that they entered. It gave them the 'feeling that I could do it' or 'paved the way'. These quotes strongly portray how self-efficacy and outcome expectations, mediated by the relationships formed with key gatekeepers, created or strengthened interest among the participants in entering the teacher education profession. None of the participants foresaw a career in higher education until they were invited and encouraged and their career expectations were altered. This is exemplified by Josh, who, having explained that he had developed an interest in joining the university, went on to explain that it was the influence of an existing staff member who turned his interest into a choice and subsequent action: 'He kind of pushed me into it. You know, it's hard to leave something you've been doing for a long, long time and try something different. Especially when I was successful'. These instances of existing faculty members encouraging teacher educators to pursue doctorates or teacher educator roles were similar to those found among literacy teacher educators by Kosnik et al. (2013).

Within teacher education, participants went on to make new career choices and professional relationships continued to be influential at key career landmarks.

\section{Key career landmarks}

When asked to identify landmarks or turning points in their professional journeys, specific achievements, such as attaining a master's or $\mathrm{PhD}$ or reaching full professorship, as well as changing from one institution to another, were common and not unexpected responses. In addition, most participants noted as landmarks meeting people who would go on to provide mentorship and support during their careers:

He's just been an immense mentor for me, just huge. He directed opportunities, because he was heavily involved in leading in physical education and education, he gave opportunities to me, or directed me towards opportunities . . . And then if I needed help he would be there to help me. And he's just been absolutely huge really. He's mentored me, you know, for years. (Jane, New Zealand)

In my very first job at university, I became acquainted with a more senior professor . . . he became sort of an informal mentor and sort of gave me some heads-ups and kind of kept me from making mistakes and pointed me in the right direction. (Ian, USA) 
Some of the factors influencing the decisions participants made regarding their careers, such as the decision to do a master's or $\mathrm{PhD}$, to become a teacher educator, to go for promotion or to change institutions, included interest factors such as a wish to do more research or to have a stronger impact on teachers and young people and more practical factors such as family circumstances, a desire for job security or a $\mathrm{PhD}$ being a requirement within a position. The impact of professional relationships on the career decisions participants made was also clear in the data. Ian and Lars, for example, were strongly encouraged by their mentors to pursue their careers in teacher education:

By the middle of spring semester, that's when [my master's supervisor] and I started to have some conversations about, you know, carrying on and doing more. Because basically, what he argued was that, you know, a master's degree is nice and dandy but it really doesn't help you that much and he said, you know, you've got the tools, you've got the energy, the interest. I think you would be a very good potential doctoral student. (Ian, USA)

Then we had a meeting together and he said . . 'you are in a very nice position, a very nice moment and very nice context to get this position and then if you are doing your best you have a chance to become a permanent assistant here and to have a permanent job for the rest of your life'. (Lars, Belgium)

Andreas, on the other hand, was influenced by the advice of his peers:

I was talking to some $\mathrm{PhD}$ applicants and they told me that, sure, there are opportunities, but you should look at the conditions, there are non-permanent positions, there are fifty-percent positions and so on, you should think about that. Then I decided if there's a chance, why not? I can always go back to school. (Andreas, Germany)

Again, we see the interaction between self-efficacy, outcome expectations and career interests, goals and actions. As found by Dodds (2005), the relationships many of our participants developed with mentors resulted in exposure to professional opportunities, advice on how best to navigate career decisions and, as will be discussed in the next section, significant professional learning.

The mentoring relationships enjoyed by participants were largely informal and some had multiple mentors throughout their careers. It is notable that not all participants had mentors. Andreas (Germany), for example, comparing his journey with that of a colleague, commented: 'I wouldn't say that I had a mentor the whole time. It was more like a sort of patchwork mentoring. It was something here and there . . . in comparison to [a colleague], he was more in the pathway of [his mentor] . . like in the [wake] of a ship driving along.'

A number of participants also experienced negative relationships which had direct impacts on their career decisions. One participant had his freedom and autonomy curtailed by a powerful colleague and went on to explain that this had the effect of motivating him to reach for a higher position where he would have more autonomy and not have this feeling of 'being an employee' again: 
There was this colleague, and I never thought I should be grateful to him for that, who let me feel what it is to be an employee, to be told what to do ... and there were two more colleagues that he told what to do and which literature to search for him and so on. And I realized that I suffered. I suffered from losing my independence that I had had. (Max, Switzerland)

There were also two other examples of participants who each found themselves working with people with whom they did not share professional values or outlooks, and this impacted their career decisions. In one case, the participant decided to leave her position because she felt her work, and that of her mentor, was being undermined by a person in a senior role with responsibility for the programme. She did not foresee this situation improving and felt that she did not wish to remain in the position and witness the work she had done with her mentor being unravelled by someone who did not have the same professional outlook or perspective regarding what was best for the programme. In the other case, the participant found herself surrounded by colleagues with whom she did not agree on key professional concerns. However, she chose to stay until the situation improved. In the case of the first participant, she did not foresee a positive change in circumstance, which is why she was prompted to leave. The other participant stayed because she believed in the possibility of things improving. Outcome expectations, therefore, were key to these participants' career decisions in the context of unsupportive relationships. These examples show that it is not as simple as supportive relationships leading to career development and unsupportive relationships being career limiting. Rather, as Lent et al. (1994) point out, contextual factors can moderate the relationship between interest and choice and between choice and action.

\section{Professional learning}

According to Hodkinson (2008: 11), 'learning, like career decision-making, is an integral part of living, not a separate process that takes place in a separate context'. Lent et al. (1994) emphasise the importance of learning experiences in interaction with personal and contextual factors and in guiding career development. Learning experiences are seen to shape outcome expectations and self-efficacy, which in turn affect interests, goals and actions. Whilst much of the professional learning of participants in this study took a self-directed form, many found that their relationships with mentors, colleagues and students were also formative and enhanced their professional learning and understanding of their roles:

The discussions [I have with my mentor], our impromptu discussions or talking over lunch or at conferences or just sitting in the office. Those things shaped how I feel about teaching and learning ... I am like I am because of the things that he told me while I was studying ... that shaped the whole way I think about being a teacher educator, you know, a professional in this field. (Josh, USA)

I read a lot. I picked people's brains a lot. I targeted people that I thought were really knowledgeable and supportive and I did have lots of philosophical discussions with a couple of people. You know, like, we did have quite a strong sort of group of I guess now we'd call them critical friends. And we did chew the fat a lot and challenge each other a lot. So a lot of [professional learning] I guess I did that way. (Olivia, New Zealand) 
Considering the influence of relationships on professional learning, the data also uncovered the sometimes non-linear form professional learning can take in the context of professional journeys. Because of the somewhat ad-hoc, unplanned way in which some participants' careers developed, they found that they had significant gaps in their professional learning and it was when they formed new relationships later in their careers that they were afforded the opportunity to become learners again and fill these gaps. Sara, based in Ireland, for example, described the impact on her professional learning when a new colleague joined her department: 'what I've learned from her in relation to professionalism, how to conduct yourself, how not to conduct yourself, how to consider things, the sort of bigger role of being an academic'. Similarly, Cathy shared how forming relationships with new colleagues in the latter years of her career gave her the opportunity to become a learner and 'fumble around' in ways she had not had the opportunity earlier in her career:

I was seen to always be leading and guiding people . . . Because I hadn't been in a place that had [colleagues I could partner with] or I was always senior faculty . . . I didn't have the chance to grow up ... And so since [I met two recent colleagues], they provided the same kind of personalities. I got to step back ... I never had a chance to fumble around like a child does (Cathy, Ireland).

Livingston et al. (2009) note that here has been a growing demand in recent decades for teacher educators to become research active. They root this increased demand partially in the external pressures brought to bear through institutional audit procedures that have come to pervade higher education institutions (particularly universities) in many countries. A number of participants, when discussing the various roles they embodied as teacher educators, explained that as they progressed through their careers they gradually took on more administration and leadership positions and this often prevented them spending as much time as they would like conducting their own research and keeping up to date with scholarship. In these cases, many saw their relationships with graduate students as key to maintaining their connection to the scholarly aspect of their roles. As Karl (Germany) explained, he is 'being sort of kept up with research through the students that I am advising'.

Harrison and McKeon (2008) have identified conversations with colleagues as a key facilitator of professional learning. Such supportive conversations, and the relationships in which they are embedded, can be instrumental in helping teacher educators to construct their professional identities, allowing them to feel part of a professional community and laying the foundation for their professional learning (Izadina, 2014; Williams and Ritter, 2010).

\section{Concluding comments}

Hodkinson (2008) argues that career decision-making is never an exclusively individual act and that the actions of others have a significant influence. The theme of professional relationships was not one that was anticipated from the outset of this research, nor was it a direct focus of any of the interview questions. Rather, the importance of other people in the professional lives of teacher educators became apparent throughout the analysis process. From the perspective of SCCT (Lent et al. 1994), relationships with, and influences of, others mediated the links between participants' interests, choices and performance. Cycles of interest development, career choice and performance were strongly affected by the people 
with whom participants formed relationships throughout their careers. Positive or negative reinforcement was seen to encourage or discourage a particular career choice, depending on the outcomes participants anticipated and the value they placed on such outcomes.

Within the cases studied, the data uncovered the social dimension of the teacher education profession and, accepting that question-raising can be as important as answer-giving (Lawson, 1984, 2013), we now consider what this may mean for the preparation and support of teacher educators at all stages of their careers.

The first point we consider is the evident influence existing staff can have on who enters and progresses within the teacher education profession. Most participants were identified as potentially suiting the role by existing teacher education faculty and were encouraged by them to enter higher education. It may well be that such existing faculty encouraged many promising colleagues and only some remained in the profession. However, the mere fact of the existence of such encouragement and influence is rarely a focus in the literature. The social construction of research communities within physical education is discussed at length by Lawson (2009) and our findings suggest that some of the concepts to which he refers, such as networks and gatekeepers, have significant discursive value within teacher education more broadly.

Vroom (1964: 56) argues that 'people not only select occupations, they are selected for occupations'. Reflecting on Vroom's point, Lent et al. (1994) remind us that choice attainment depends in part on the degree to which an individual meets vocational requirements. This is particularly significant given the stress policy makers are increasingly placing on the importance of teacher educator recruitment and selection (European Commission, 2013, 2017). The vocational requirements of the teacher education profession, however, have not been well defined internationally and this has resulted in a certain 'freedom of decision' among those responsible for teacher education recruitment (Caena, 2013: 7). Because teacher educators are involved in the design and implementation of teacher education programmes, as well as the research on which such programmes are founded, the selection and support of such teacher educators is arguably one of the most important tasks existing staff can undertake and must require a number of related competencies worthy of exploration. Koster et al. (2005), in their professional profile of teacher educators, based on a Delphi study in the Netherlands, identified 27 tasks teacher educators 'have to do' and 29 competencies teacher educators 'should possess'. It is notable that while the selection and support of future teachers featured in the profile, the selection and support of future teacher educators was not mentioned. While much emphasis is correctly placed on teacher educators recruiting and supporting prospective school teachers, their role in recruiting and supporting each other is also worth considering further.

The second point we consider is the support and advice teacher educators give to each other throughout their careers. Koster et al. did mention 'giving guidance and support to, and receiving guidance and support from colleagues' in their professional profile of teacher educators (2005: 166). It was evident in our study that the influence of professional relationships was significant in shaping the identity, values and priorities of our participants, in addition to influencing the career decisions they made. Research by Richards et al. (2017) 
suggests that the importance of supportive relationships is also significant for today's early career teacher educators. In the context of the changing higher education landscape with increasing expectation and pressure on early career academics (Alfrey et al., 2017), the truism holds that history may not repeat but it rhymes. We suggest that professional relationships have always and will always be influential in the professional development and learning of teacher educators. Acknowledging this and exploring its implications further may be helpful in supporting future teacher educators.

Given the support, advice, modelling and opportunities many of our participants enjoyed as a result of professional relationships fostered throughout their careers, we wonder how, if at all, has the formalisation of mentoring relationships at higher education institutions in many countries and the increase in transparency and accountability for recruitment and promotion practices affected teacher educators' sense of belonging, clarity of direction and purpose, suitability for their roles and professional learning and development? It would be useful to explore further how professional relationships are affecting, and being affected by, careers in physical education teacher education today. Further, an exploration of the professional journeys of those who decided to move away from careers in teacher education may serve to further uncover the forces shaping the journeys of teacher educators. Just as teacher attrition research has given valuable insights into what might need improvement in the teaching profession and how teachers might best be supported in their roles, some work into teacher educator attrition may be warranted.

\section{References}

Alfrey L, Enright E and Rynne SB (2017) Letters from early career academics: the physical education and sport pedagogy field of play. Sport, Education \& Society 22(1): 5-21.

Bandura A (1986) Social foundations of thought and action: A social cognitive theory. Englewood Cliffs, NJ: Prentice-Hall.

Ben-Peretz M, Kleeman S, Reichenberg R and Shimoni S (2010) Educators of educators: their goals, perceptions and practices. Professional Development in Education 36(1-2): 111129.

Bloch C (2012) Passion and paranoia: Emotions and the culture of emotion in academia. London: Routledge.

Boyd P and Smith C (2016) The contemporary academic: orientation towards research work and researcher identity of higher education lecturers in the health professions. Studies in Higher Education 41(4): 678-695.

Bronkhorst LH, Meijer PC, Koster B and Vermunt JD (2011) Fostering meaning-oriented learning and deliberate practice in teacher education. Teaching and Teacher Education 27(1): 1120-1130.

Caena F (2013) Education: Policy support for teacher educators. Perspectives on teacher educator policies in European countries: an overview. Working document. Strasbourg: European Union. 
Casey A and Fletcher T (2012) Trading places: from physical education teachers to teacher educators. Journal of Teaching in Physical Education 31(4): 362-380.

Dodds P (2005) Chapter 4: PETE women's experiences of being mentored into postsecondary faculty positions. Journal of Teaching in Physical Education 24(4): 344-367.

Elliott R and Timulak L (2005) Descriptive and interpretive approaches to qualitative research. In J. Miles \& P. Gilbert (Eds.), A handbook of research methods for clinical and health psychology (pp. 147-159). Oxford: Oxford University Press.

Enright E, Alfrey L and Rynne SB (2017) Being and becoming an academic in the neoliberal university: a necessary conversation. Sport, Education and Society 22(1): 1-4.

Erickson LB, Young JR and Pinneger S (2011) Teacher educator identity: Emerging understandings of person, positioning, roles, and collaborations. Studying Teacher Education 7(2): 105-107.

European Commission (2013) Supporting teacher educators for better learning outcomes. Strasbourg: Author.

European Commission (2017) Modernisation of higher education in Europe: Academic staff. Eurydice report. Strasbourg: Author.

Fletcher T and Casey A (2014) The challenges of models-based practice in physical education teacher education: a collaborative self-study. Journal of Teaching in Physical Education 33(3): 403-421.

Gelfuso A (2017) Facilitating the development of preservice teachers' Pedagogical Content Knowledge of literacy and agentic identities: Examining a teacher educator's intentional language choices during videomediated reflection. Teaching and Teacher Education 66: 3346.

Griffiths V, Thompson S and Hryniewicz L (2014) Landmarks in the professional and academic development of mid-career teacher educators. European Journal of Teacher Education 37(1): 74-90.

Harrison J and McKeon F (2008) The formal and situated learning of beginning teacher educators in England: identifying characteristics for successful induction in the transition from workplace in schools to workplace in higher education. European Journal of Teacher Education 31(2): 151-168.

Hodkinson P (2008) Understanding career decision-making and progression: Careership revisited. John Killeen Memorial Lecture, Woburn House, London, 16th October 2008. Retrieved from http://www.crac.org.uk/cms/files/upload/fifth_johnkilleenlecturenotes.pdf

Hökkä P, Vähäsantanen K and Mahlakaarto S (2016) Teacher educators' collective professional agency and identity - Transforming marginality to strength. Teaching and Teacher Education 63: 36-46. 
Izadinia M (2014) Teacher educators' identity: A review of literature. European Journal of Teacher Education 37(4): 426-441.

Kirk D (2014) Making a career in PESP in the corporatized university: reflections on hegemony, resistance, collegiality and scholarship. Sport, Education and Society 19(3): 320332.

Koster B, Brekelmans M, Korthagen F and Wubbels T (2005) Quality requirements for teacher educators. Teaching and Teacher Education 21(2): 157-176.

Kosnik C, Menna L, Dharamshi P, Miyata C and Beck C (2013) A foot in many camps: literacy teacher educators acquiring knowledge across many realms and juggling multiple identities. Journal of Education for Teaching 39(5): 523-540.

Kosnik C, Miyata C, Cleovoulou Y, Fletcher T and Menna L (2015) The education of teacher educators. In T. Falkenberg (Ed.), Handbook of Canadian research in initial teacher education (pp. 207-224). Ottawa, ON: Canadian Association of Teacher Education.

Kovar SK (2004) The thirty-eighth Amy Morris Homans commemorative lecture 2004: a sense of connection and direction. Quest 56(3): 267-284.

Lawson HA (1991) Future research on physical education teacher education professors. Journal of Teaching in Physical Education 10(3): 229-248.

Lawson HA (1984) Problem-setting for physical education and sport. Quest 36(1): 48-60. Lawson HA (2009) Paradigms, exemplars and social change. Sport Education and Society 14(1): 97-119.

Lawson HA (2013) Appreciating complexity, endemic tensions and selectivity in proposals for program improvement and new institutional designs. Sport, Education and Society 18(1): 121-129.

Lee HM and Curtner-Smith MD (2011) Impact of occupational socialization on the perspectives and practices of sport pedagogy doctoral students. Journal of Teaching in Physical Education 30(3): 296-313.

Lent RW, Brown SD and Hackett G (1994) Toward a unifying social cognitive theory of career and academic interest, choice, and performance. Journal of Vocational Behavior 45(1): 79-122.

Lent RW, Brown SD and Hackett G (2000) Contextual supports and barriers to career choice. Journal of Counselling Psychology 47(1): 36-49.

Lent RW, Brown SD and Hackett G (2002) Social cognitive career theory. In D. Brown and Associates (Eds.), Career choice and development (4th ed.) (pp. 255-331). San Francisco, CA: Jossey-Bass.

Livingston K, McCall J, and Morgado M (2009) Teacher educators as researchers. In A. Swennen \& M. van der Klink (Eds.), Becoming a teacher educator. Theory and practice for teacher educators (pp. 191-203). Dordrecht: Springer. 
Loughran J and Hamilton ML (Eds.) (2016) International handbook of teacher education. Vol. 2. Amsterdam: Springer.

MacPhail A (2011) Professional learning as a physical education teacher educator. Physical Education and Sport Pedagogy 16(4): 435-451.

MacPhail A (2017) 'Physical education and sport pedagogy' and the three 'A's: apprenticeship, academia and administration. Sport, Education \& Society 22(5): 669-683.

McEvoy E, MacPhail A and Heikinaro-Johansson P (2015) Physical education teacher educators: A 25-year scoping review of literature. Teaching and Teacher Education, 51: 162181.

Mayer D, Mitchell J, Santoro N and White S (2011) Teacher educators and 'accidental' careers in academe: An Australian perspective. Journal of Education for Teaching: International Research and Pedagogy 37(3): 247-260.

Mitchell MF (1992) Scholarly behaviors of physical education methods teacher educators in Ohio. Journal of Teaching in Physical Education 11(3): 303-314.

Montenegro Maggio H (2016) The professional path to become a teacher educator: the experience of Chilean teacher educators. Professional Development in Education 42(4): $527-$ 546.

Morberg A and Eisenschmidt E (2009) Second-phase induction for teacher educators: Challenges and possibilities. In A. Swennen \& M van der Klink (Eds.), Becoming a teacher educator. Theory and practice for teacher educators (pp. 103-113). Dordrecht: Springer.

Patton MQ (2002) Qualitative research and evaluation methods (3rd ed.). London: Sage.

Richards KA, McLoughlin GM, Shriver VN and Lux K (2017) Understanding physical education doctoral students' perspectives of socialization. Journal of Teaching in Physical Education 36(4): 510-520.

Rubin HJ and Rubin IS (1995) Qualitative interviewing: The art of hearing data. London: Sage.

Russell T and Loughran J (2010) Probing the depths of a teacher educator's work. Studying Teacher Education 6(1): 1-2.

Silverman D (2013) Interpreting qualitative data (4 ${ }^{\text {th }}$ ed.). London: Sage.

Smith B and McGannon KR (2017) Developing rigor in qualitative research: problems and opportunities within sport and exercise psychology. International Review of Sport and Exercise Psychology. Epub ahead of print 14 May 2017. DOI:

10.1080/1750984X.2017.1317357

Swennen A and Bates T (2010) The professional development of teacher educators. Professional Development in Education 36(1/2): 1-7. 
Swennen A and Van der Klink M (Eds.) (2009) Becoming a teacher educator: Theory and practice for teacher educators. Amsterdam: Springer.

Tannehill D (2005) Back to the future: we listened and we learned. Quest 57(3): 287-299.

Teddlie C and Yu F (2007) Mixed methods sampling: A typology with examples. Journal of Mixed Methods Research 1(1): 77-100.

Tryggvason M-T (2012) Perceptions of identity among Finnish university-based subject teacher educators. European Journal of Teacher Education 35(3): 289-303.

Van der Klink M, Kools Q, Avissar G, White S and Sakata T (2017) Professional development of teacher educators: what do they do? Findings from an explorative international study. Professional Development in Education 43(2): 163-178.

Vanassche E and Kelchtermans G (2014) Teacher educators' professionalism in practice: Positioning theory and personal interpretative framework. Teaching and Teacher Education 44: 117-127.

Vroom VH (1964) Work and motivation. New York: Wiley.

Williams J and Hayler M (Eds.) (2015) Professional learning through transitions and transformations: Teacher educators' journeys of becoming. Amsterdam: Springer.

Williams J and Ritter JK (2010) Constructing new professional identities through self-study: from teacher to teacher educator. Professional Development in Education 36(1-2): 77-92. 